\title{
The Effect of Learning Strategy and Achievement Motivation on Civic Education Learning outcomes (A Study on Students at STKIP Bangkalan East Java, Indonesia)
}

\author{
Sunardjo, Suko Wiyono, Sihkabuden \\ Graduate Program, Universitas Negeri Malang
}

\begin{abstract}
This study aims to determine differences in learning outcomes between groups of students taught by contextual learning strategy and conventional one, high achievement motivation and low, as well as the interaction effect of learning strategies and achievement motivation on learning outcomes for civic education course. Quasi-experimental study was conducted with a 2x2 factorial design, non-equivalent control group design. The subjects are 74 students of STKIP PGRI Bangkalan from two classes of Civic Education course participants, selected by using purposive cluster sampling. Class A with 36 students designated as an experimental class and class $\mathrm{C}$ with 38 students as a control class. Data analysed with two-way ANOVA. The findings of the study showed differences in student learning outcomes based on learning strategies and achievement motivation. On the other hand, the interaction variable of learning strategies and achievement motivation has significant effect on student learning outcomes.
\end{abstract}

Keywords: Contextual Learning Strategies, Achievement Motivation, Learning Outcomes for Civic Education Course.

\section{INTRODUCTION}

Civic Education Learning course has not yet to show maximum effort in achieving the learning objectives as stated in the curriculum. Although the values have been incorporated into the curriculum, but in practice there are many irregularities. The values in the curriculum are more widely taught in a concept form. Lecturer more everyday teaching definitions of concepts and values, and does not seek to make the learning process that leads to the process of internalization, personalization, and applications of students rated themselves in life (Abdul and Sapriya, 2011). This condition is seen from the dominant learning teaching method which is monotonous without regard to student characteristics, not involving the environment as a learning resource, and optimally not yet applied into learning approach that emphasizes the moral value education.

Their weaknesses in teaching methods for Civic Education make the mission to form citizens who have a democratic and participatory still far from the expectation. Some lecturers have yet implemented the learning process with contextual approach as daily life faced by the students. In fact, the frontline to achieve the mission for Civic Education is the hard work from faculty to develop innovative and creative approaches that are relevant (Samsuri, 2011:3). Seeing the lack of student learning outcomes that are achieved, it is necessary to make reflection and improvement in the learning process in the classroom, including the process of assessment. We need to think about the use of learning strategies that can excite and interest of student learning, so that learning materials is easily understood and meaningful for living. One of the alternative learning strategies that can be used is the Contextual Teaching and Learning strategy. According to Johnson (2007) this strategy is the cornerstone of the philosophy that success in learning characterized by the ability to interpret the content and academic work and linking new information with knowledge and experience owned by learners.

In the researcher's view, a very precise contextual learning strategies used in the Civics course. New knowledge and skills acquired by students not by rote, but through Learning by Doing and Leaning by Discovery. Civic Education course is full of moral values to form a noble character, and cannot be achieved only through a series of theories or tasks that do not have meaning, it is not able to connect between new knowledge prior knowledge, and cannot be realized in real life.

Schools need to create learning communities that can provide meaningful experiences for students, and develop methods of scientific discovery learning environment that is democratic (Dewey, 1916). Contextual learning has actually been applied in Indonesia by Taman Siswa University since 1926. Ki Hajar Dewantara practice Among (parenting) systems that supports the natural nature of the students and not forcing the students to grow and develop in accordance with nature; but the implementation of the learning process takes place through the close connection between thinking and doing (Riyanto, 2008). 
Contextual learning evolved by various terms such as Realistic Mathematics Education in Holland which explains that learning is associated with a real life. In America, Contextual Teaching and Learning term put its focus on associating the subject matter with real life; and to motivate students to incorporate knowledge learned in their life. In Michigan evolve Connected Mathematics Project, and in Indonesia grow in terms of contextual learning. Contextual learning linking what is taught to students in a real-world situation, and encourages students to make connections between knowledge possessed by its application in everyday life (Nurhadi, 2009). Students' skills development process of reconstructing her new knowledge to solve problems in the provision of life as members of families, communities, and citizens (Johnson, 2007).

Contextual learning in Civic Education courses based on the philosophy of constructivism, which assume that knowledge is constructed by human through interaction with objects, phenomena, experiences, and their environment. Knowledge is considered correct when useful to face and solve problems or phenomena. Contextual learning based on several theories of learning, including the theory of cognitive development, free discovery learning, meaningful learning, genetic law of development, and the zone of proximal development.

Contextual learning is very different from conventional learning strategies, which functions as a means of verbal communication between faculty and students in the learning process. Learning is characterized by the use of the lecturing method that comes with an explanation, the division of tasks and learning. The process emphasis on custom, consensus, agreement that is bound to the terms, rules, or the composition that is applied regularly in daily learning (Slavin, 2007). This learning strategy is centred on the lecturer, with sequential activities, structured and has purpose to transfer knowledge of lecturers to students.

Conventional learning emphasizes the expansion of knowledge, learning as a process of imitation, and being evaluated through standardized tests (Brooks and Brooks, 1993). The success of this learning program assumes that if the entire material contained in the curriculum has been informed, the students are expected to reveal the back when given a number of questions. Knowledge is an object that can be diverted, memorization and drills dominate the learning process. Learning just as the activity of providing information and does not empower the students.

Messaging mode of learning with the conventional strategy is done through the provision of information (telling), rarely used demonstration or provides the opportunity for students to showcase direct demonstration. The lecturer's performance is more often use lecturing by following the sequence of delivery of material as contained in the curriculum. Lecturers assume that the success of learning programs seen from the thoroughness with learning resources in the form of verbal information obtained from textbooks and professors explanation.

In addition to learning strategies, the level of learning achievement is also due to the influence of internal and external factors (Degeng, 2001). One of internal factors that is closely linked with student achievement is the achievement motivation. Motivation is an expectancy value, which assumes that the tendency of individuals to engage in activities relating to the completion of a cognitive power of hope. With those expectations, behaviour will lead to consequences or particular achievement. Every individual has the motivation of achievement or motivation away from a failed to a different level. Strong achievement motivation directs people to approach the situation with regard to achievement. Achievement motivation is seen as a driver of behaviour, affect what is learned, when to learn, how to learn, and a tendency to work on strength, overcome obstacles and try to do something that is hard as well and as quickly as possible (Schunk, 2012; Murray in Degeng, 2001). The article results of this study describes the effect of the use of learning strategies and achievement motivation on learning outcomes for Civic Education course on student of STKIP Bangkalan.

\section{METHOD}

Quasi-experimental research was carried out by using a $2 \times 2$ factorial design, non-equivalent control group design. Subjects are 74 students, two classes are taken by purposive cluster sampling technique, which is one class as an experimental group with the treatment in the form of contextual learning strategies and the class as a control group treated with conventional learning strategies. Data were analysed by using two-way ANOVA. The composition of the study subjects are as follows.

Table 1. Subject of the Research

\begin{tabular}{|lllll|}
\hline & & \multicolumn{2}{l}{ Learning Strategy } & \multirow{2}{*}{ Total } \\
\cline { 2 - 5 } & Contextual & Conventional & \\
\hline \multirow{2}{*}{ Achievement Motivation } & Low & 24 & 13 & 37 \\
\cline { 2 - 5 } & High & 12 & 25 & 37 \\
\hline Total & & 36 & 38 & 74 \\
\hline
\end{tabular}




\section{RESULTS AND DISCUSSION}

The final test result on the research subjects good on experimental group and control group is shown in the following table.

\begin{tabular}{|l|l|l|l|l|}
\hline Learning Strategy & $\begin{array}{l}\text { Achievement } \\
\text { Motivation }\end{array}$ & Mean & $\begin{array}{l}\text { Standard } \\
\text { Deviation }\end{array}$ & $\mathrm{N}$ \\
\hline \multirow{5}{*}{ Contextual } & Low & 44,29 & 7,66 & 24 \\
\cline { 2 - 5 } & High & 61,83 & 9,09 & 12 \\
\cline { 2 - 5 } & Total & 53,06 & 11,62 & 36 \\
\hline \multirow{5}{*}{ Conventional } & Low & 47,15 & 4,98 & 13 \\
\cline { 2 - 5 } & High & 50,36 & 6,29 & 25 \\
\cline { 2 - 5 } & Total & 48,76 & 6,01 & 38 \\
\hline & Low & 45,72 & 6,91 & 37 \\
\cline { 2 - 5 } & High & 56.10 & 9,02 & 37 \\
\cline { 2 - 5 } & Total & 50,91 & 9,12 & 74 \\
\hline
\end{tabular}

Based on the results of the study, the mean value of the study subjects who obtained contextual learning strategy is higher than the research subjects that received conventional learning strategies. The test results by using the technique of analysis of variance of two lanes (two-way ANOVA) on the value of learning outcomes Civic Education course showed that there were differences among the study subjects who obtained with contextual learning strategies and conventional $(\mathrm{p}=0.000)$. It supports the achievement of learning outcomes concepts, principles, and theories of the application of contextual learning strategies.

These findings have implications that Civic Education lecturers should be careful and precise in selecting, developing, and implementing appropriate learning strategies to clump and characteristics of scientific disciplines. This is consistent with the mission of learning Civic Education to give education and train a set of knowledge, values, ethics, and basic skills as citizens responsible for the survival and integrity of the country and also become citizens good. This contextual learning is essentially train students to solve the problem critical thinking and complex in discovering the meaning of learning for real life. The Implementation contextual learning strategies in the learning process requires the Civic Education course lecturers are able and willing to arrange the stages of learning relevant and implemented in accordance with the procedure. The application of contextual learning strategies in the course Civics demanding high readiness. The lecturers must observe every student in the classroom in order to understand the state of emotion, learning styles, language skills, cultural context, and background, and socio-economic situation of the family.

The results showed that the contextual learning strategy is able to activate the students. They are given the opportunity to address issues that are contextual and work collaboratively in small groups, and in turn presented the results of the working class. Learning activities like these provide meaningfulness and not simply an activity for receiving and memorizing the material presented by the lecturers.

A meaningful learning activity requires a strategy of organizing the material and instructional delivery specifically. The learning packaging is often based on assumptions that are not in line with the nature of learning, the nature of the learning, and the nature of the teaching, so that less encouraging meaningful learning (Degeng, 2000).This assumption is encouraging students in rote learning. The most important in Civic Education course learning is to develop understanding and thinking about the strategies used to overcome the problems. Lecturers need to understand and know about how to use and apply the concepts Civic Education course to address the issues in everyday life. Smaldino, et al. (2005: 8) stated that "... rote learning leads to inert knowledge we know something but never apply it to real life". This is a weakness of learning that emphasizes the product (content based) and ignores the process, but an understanding of the product, cannot be achieved without understanding the process in how to achieve it. In contextual learning strategy, the emphasis on the process of learning activities, so that students experience a deeper learning through activities address the problem, and not just know and remember the content of the learning materials.

In the application of contextual learning strategy, students are facilitated to construct knowledge that is done through problem solving, information gathering, discussion, and present the result of problems in the course. Problem solving in Civic Education requires freedom, judgment, creativity, and knowledge possessed by students to build new knowledge. The use of contextual learning strategy is in line with real situations. Students learn through problem solving experience and can learn the content and strategy. Therefore, contextual learning strategy will train and familiarize the students to always think critically to face learning problem. Students learn how to organize complex problem rather than solving a problem with one correct answer.

Furthermore, the hypothesis test shows that there are differences in learning outcomes between students with high achievement motivation and students with low achievement motivation. Those who have high achievement motivation achieve better learning outcome. The result of learning outcomes in the classroom

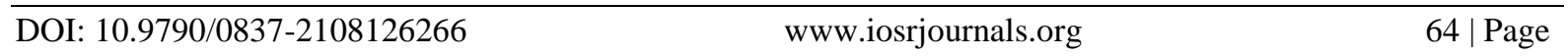


observation appears that those with high achievement motivation are more diligent, meticulous, and aggressive in following and working on the problems of Civic Education course, and finished on time.

There is also an interaction effect of dependent variable. The effect of interaction occurs between the learning strategies and achievement motivation variable on the results of this study corroborate the findings of the students. The first findings have no differences in student learning outcomes in Civic Education course taught with different learning strategy that is presented as follows.

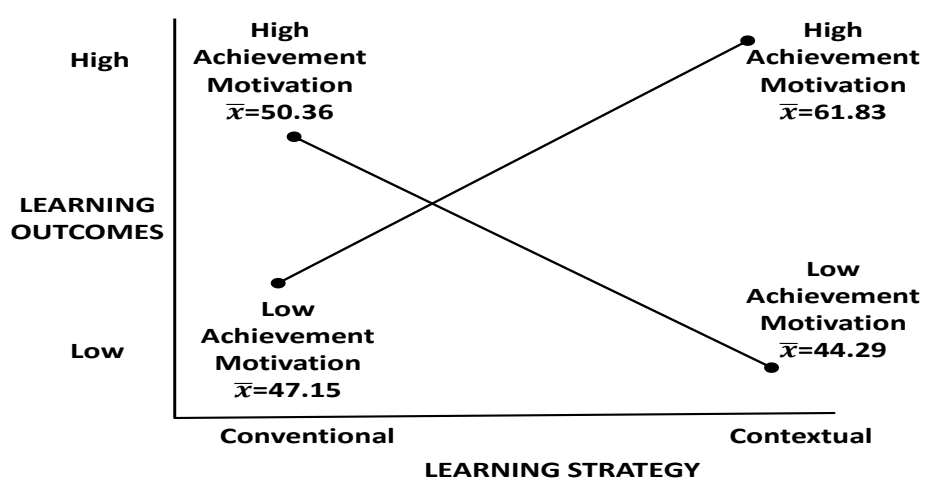

Figure 1. Interaction Effect of Learning Strategy and Achievement Motivation on Learning Outcomes

These findings have implications on Civic learning education courses. To improve learning outcomes for Civic Education courses, lecturers may consider the use contextual learning strategy through the filing of problems to be solved by the students. The problem can be constructed by faculty or by students themselves. With this strategy, students are required to take an active role in solving the problem, gather information, exchange ideas, and work collaboratively, so that they experience the learning process meaningful.

Lecturers need to look Civic Education course material, selecting the points of discussion that raises contextual issues in accordance with the real situation in everyday life. Contextual learning strategy implementation requires faculty and students to be actively and creatively involved in the learning process. Lecturers and students have to exert effort and act according to their own responsibility in learning, and this is necessary for creativity in finding resources for problem solving.

The big difference in learning outcomes between groups of students based on motivation underachievement, lecturers should give attention to the students. For characteristics, motivation to make achievement refers in designing, developing, managing, and evaluating the learning. Similarly, the interaction between the learning strategies and motivation to make achievement on learning outcomes indicate that the main influence on learning outcomes is true. In other words, the findings of this study reinforce differences in learning outcome taught with different learning strategies. Based on these findings, the lecturers should choose strategies that contribute to increased student learning outcomes in supporting civic education learning.

\section{CONCLUSION AND RECOMMENDATION}

Based on the general description, hypothesis testing, and discussion can be concluded that there is a difference in student learning outcomes in Civic Education among the group of students who were treated using contextual learning strategy compared with conventional learning strategy. The achievement for contextual learning strategy student learning outcomes is higher than conventional learning strategy. Similarly, there is a difference among the group of students who have high achievement motivation and low achievement motivation. Those who have high achievement motivation have better learning outcomes than those who have low achievement. On the other hand, achievement motivation, the interaction between the learning strategies and achievement motivation also significantly influence the learning outcomes. The implementation of contextual learning strategies to students who have high achievement motivation gives better learning performance than the use of conventional learning strategies.

Based on these results, it is recommended that in Civic Education course, the lecturers can use contextual learning strategies which are appropriate to the students' need. Then, they should design specific characteristics, designing learning activities systematically based on discovery and inquiry, learning in groups, learning by using real examples and models contained in the student's daily life as a student-centred learning. At the end, the students are able to solve problems and having learning experience in a more meaningful way. 


\section{REFERENCES}

[1] Abdul, A.W. \& Sapriya, 2011, Teori dan Landasan Pendidikan Kewarganegaraan, Bandung: Alfabeta CV.

[2] Brook, J.G \& Brook, M.G.T. 1993. In Search of understanding: the case for constructivist classrooms. Norfolk: Association for Supervision and Curriculum Development.

[3] Degeng, I.N.S. 2001. Kumpulan Bahan Pembelajaran, Menuju Pribadi Unggul Lewat Perbaikan Kualitas Pembelajaran di Perguruan Tinggi. Malang: Universitas Negeri Malang, LP3.

[4] Degeng, I.N.S. 2000. Paradigma baru pendidikan memasuki era demokratisasi belajar. Makalah disajikan dalam Seminar dan Diskusi Panel Nasional Teknologi Pembelajaran V, Program Studi Teknologi Pembelajaran Program Pascasarjana Universitas Negeri Malang Bekerja Sama dengan Ikatan Profesi Teknologi Pendidikan Indonesia (IPTPI) Cabang Malang, Malang, 7 Oktober.

[5] Dewey, J. 1916. Democracy and Education: An Introduction to the Philosophy of Education, New York: Free Press.

[6] Johnson, E.B, 2007. Contextual Teaching and Learning Kegiatan Belajar Mengajar Mengasyikan dan Bermakna. Terjemahan: Contextual Teaching and Learning: what it is and why it's here to stay, oleh: Setiawan, I. 2007, Bandung: MLC.

[7] Nurhadi, 2009. Pembelajaran Kontekstual (CTL). Malang: Pascasarjana UM.

[8] Riyanto, Y.2008. Paradigma Baru Pembelajaran. Jakarta: Prenada Media.

[9] Samsuri, 2011, Bahan Kajian Kuliah Umum di Program Studi Pendidikan Pancasila dan Kewarganegaraan (PPKn) FKIP Universitas Ahmad Dahlan, Yogjakarta, 9 Mei 2011. Makalah disajikan dalam diskusi tentang best practices pembelajaran PKn, dalam kajian mandiri kewarganegaraan di Program Studi PIPS Sekolah Pascasarjana Universitas Pendidikan Indonesia, Bandung.

[10] Schunk, D.H. 2012. Teori-teori Pembelajaran: Perspektif Pendidikan. Terjemahan: Learning Theories, oleh: Hamdiah, E \& Fajar, R. 2012. Yogjakarta: Pustaka Belajar.

[11] Slavin, R E. 2007. Instructional Technology and Media for Learning ( $9^{\text {th }}$ edition). Columbus: Ohio.

[12] Smaldino, S.E, Russell, J.D., Heinich, R., \& Molenda, M. 2005. Instructional Technology and Media for Learning $\left(8^{\text {th }}\right.$ edition). New Jersey: Upper Saddle River. 